\title{
Food and Social Background of Nasopharyngeal Cancer Patients in Jakarta
}

Averdi Roezin

\begin{abstract}
Abstrak
Berbagai faktor telah dibuktikan sebagai penyebab dan predisposisi timbulnya karsinoma nasofaring (KNF) seperti Virus Epstein-Barr (EB), makanan, jenis kelamin, genetika, sosial ekonomi, lingkungan dan lain-lain. Selama 10 bulan dari Januari sampai Oktober 1996 di Bagian THT FKUI/RSUPN Dr. Cipto Mangunkusumo Jakarta didapatkan 81 kasus baru karsinoma nasofaring dan dibandingkan dengan 81 kasus bukan karsinoma nasofaring yang datang berobat yang diambil secara acak dalam waktu yang sama. Penderita laki-laki lebih banyak dari wanita $(64,20 \%: 35,80 \%)$ dengan umur rata-rata 45 tahun pada kelomnok KNF dan 34,13 tahun pada kelompok non-KNF. Diselidiki pula pendidikan, penghasilan sebulan, berat badan, energi unty sumber air minum, dan didapatkan bahwa kelompok KNF memang berasal dari golongan berpenghasilan kurang. Diter anpula bu a secara bermakna ikan asin yang dikonsumsi sehari-hari oleh kelompok KNF lebih banyak dibandingkan pada kelo merokok dan lingkungan yang polutif lebih banyak pada penderita KNF.

Abstract

Many factors have been proven as the etiological and predisposing factor asophary. sex, genetics, social economy, environment and others. During 10 months $m$. ary to October 1996 in the Department of Otorhinolaryngology, Medical Faculty, University of Indonesia we found 81 new cases sopharyngeal cancer and compared them with 81 cases of non-NPC patients in the same time. Male patients wer frequent th female (64.20\%:35.80\%); the average age was 45 years in NPC and 34.13 years in non NPC group. Educati monthly income, body weight, energy for cooking and water sources were studied. We found that the NPC patients came from ower inc group. The prominent evidence was that the consumption of salted fish as a protein source was higher in the NPC wared the non NPC group (33.33\% and 13.58\%), and this difference was statistically significant. Poluted environ as well a. ng habit were also higher in the NPC compared to the non NPC group.
\end{abstract}

Keywords: salted fish, smoking habit.

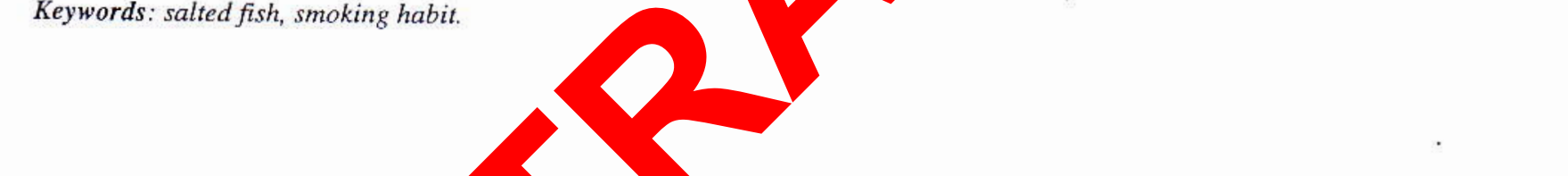

It's nearly definitive that EB-vias (B, is the etiology of nasopharyngeal cap $(\mathrm{NPC})$. B $\mathrm{BV}$ is not running alone; there are ne e rnal factors that play a role in the appearing $c$. Tho factors are genetics, age, sex social economy, culture and habi oly on, in, on and many others.

Environmental on is sed thought by many, especially in lay man, major cause of many forms of cancer. However, in, nnsive research in the last 3 decades has shown that this concept is incorrect. Lifestyle or lifestyle-related behavior can promote and cause the development of various cancer found in human. The etiological factors are often complex and need careful analysis and evaluation.

Department of Otorhinolaryngology, Faculty of Medicine, University of Indonesia / Dr. Cipto Mangunkusumo Hospital, Jakarta, Indonesia
In nasopharyngeal carcinoma, many authors had mentioned $\mathrm{EB}$ virus, genetics and diet to be the main etiological factors. The enviromental factors and/or diet factors can react with genetic material, such as DNA and should be the important one in causing NPC. ${ }^{1}$

$\mathrm{Ho}^{2}$ first proposed that Chinese salted fish, a popular food in Southern China, especially favoured by the Cantonese, was a possible factor in the development of NPC. This theory was based on the fact that the highest incidence of NPC occurs in the fisher folk of Hong Kong, whose diet contains a high proportion of salted fish and a deficient intake of vitamin-rich fresh vegetables and fruits. In Indonesia, there was no study to proof that salted fish consumption, social economic condition, culture and habit, and polution play a role in the NPC, even though Indonesian people have intermediate to high susceptibility to NPC. 
Therefore, during 10 months, from January to October 1996 in the Department of Otorhinolaryngology, Medical Faculty, University of Indonesia we studied 81 new cases of NPC and compared them to another 81 patients of non NPC. This study was focused on food and social background of the NPC and non NPC cases.

\section{METHODS}

This study was held in the Department of Otorhinolaryngology, Medical Faculty, University of Indonesia/Dr. Cipto Mangunkusumo Hospital, Jakarta, between January 1 to October 31, 1996. During that time were found 81 new cases of nasopharyngeal cancer, which consist of 52 males and 29 females. The diagnosis was based on the anamnesis, clinical examination, radiological examination - CT Scan, biopsy and histopathological finding of nasopharyngeal cancer. The control group of non NPC patients were also consist of 52 males and 29 females suffering from various diseases and normal one. The control group cases were taken randomized on the same day after each case of NPC was diagnosed. The criteria to be the control group were an adult patient and has the same sex with the NPC patient. The exclusion of NPC $y$ confirmed by the anamnesis, clinical examinat. conventional radiological examination, biopsy a histopathological examination if suspicio ther was a tumor and demonstrable signs and $\mathrm{mp}$ ns of nasopharyngeal cancer. In this contro sup had any kinds of diseases of the ear, $p$ an roat and neoplasms of the ear, nose d throa except nasopharyngeal cancer. In bo gro food an social background were studied luding a sex, occupation, education, month' ncome, body eight, main food, protein sources, er plement food, smoking habit, energy for cookin rinki water sources and housing.

\section{RESULTS}

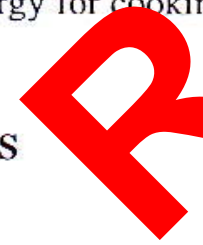

Sex

Both groups of 81 cases each, consist of 52 males (64.20\%) and 29 females $(35.80 \%)$.

\section{Age}

In NPC patients the age was ranging from 20 to 64 years and the mean was 45 years; in the control group the age was ranging from 18 to 84 years and the mean was 34.13 years (Table 1).
Table 1. Age distribution of NPC and non-NPC patients $(\mathrm{N}=81)$

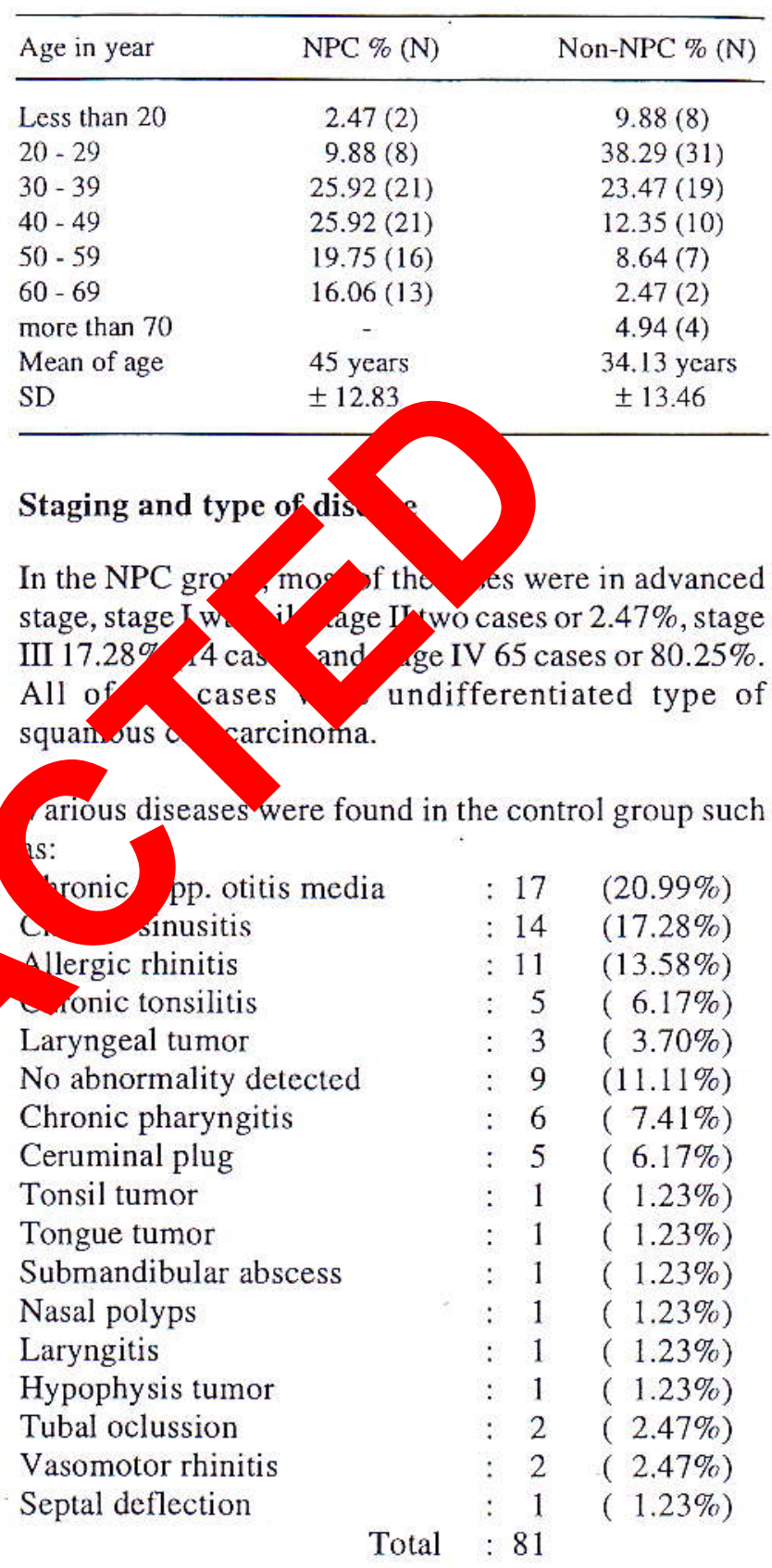

\section{Educat:on}

In the NPC group iliteracy cases were $5(6.17 \%)$, Primary School 29 (35.80\%), Secondary High School 17 (20.99\%), High School 21 (25.92\%) and University graduates $9(11.12 \%)$. In the control group, iliteracy were $2(2.47 \%)$, Primary School $9(11.11 \%)$, Secondary High School 13 (16.05\%), High School 35 $(43.21 \%)$ and University graduates $22(17.16 \%)$ (Table 2). 
Table 2. Education of the two groups $\mathrm{N}=81$

\begin{tabular}{lcc}
\hline Education & NPC \% (N) & Non - NPC \% (N) \\
\hline Iliteracy & $6.17(5)$ & $2.47(2)$ \\
Primary School & $35.80(29)$ & $11.11(9)$ \\
Secondary High School & $20.99(17)$ & $16.05(13)$ \\
High School & $25.92(21)$ & $43.21(35)$ \\
University & $11.12(9)$ & $17.16(22)$ \\
\hline
\end{tabular}

\section{Monthly income}

Most of the cases in NPC and control group had monthly income between USD 50 to 150; in the NPC group there were 42 cases $(58.03 \%)$, and in the control group there were 31 cases $(38.28 \%$ ) (Table 3 ).

Table 3. Monthly income of the two groups $\mathrm{N}=81$

\begin{tabular}{lcc}
\hline Income (USD) & NPC \% (N) & Non-NPC \% (N) \\
\hline 0 & $4.94(4)$ & $12.34(10)$ \\
$<50$ & $13.58(11)$ & $17.28(14)$ \\
$50-150$ & $58.03(47)$ & $38.28(31)$ \\
$150-250$ & $17.28(14)$ & $14.82(12)$ \\
$>250$ & $6.17(5)$ & $17.28(14)$ \\
Mean of income & 120.78 & 135.21 \\
SD & \pm 68.79 & \pm 80.32 \\
\hline
\end{tabular}

\section{Body weight}

Most of the NPC group patients have dy wht below normal $(58.02 \%)$, while the pe $\mathrm{mal}$ and above normal body weigh vas 20 , 8 and $20.99 \%$ respectively. Normal bo rht $=90, \mathrm{CH}$ -100) $\mathrm{kg}(\mathrm{H}=$ height in centimeter).

In non-NPC group, case sing below nomal, normal and above norma dy eight were $50.62 \%$, $33.33 \%$ and $16.05 \%$ spe ely. Rere was no significant differen or dy figures between both groups $(R, 0.02$

Food

Rice was the main staple in both groups as well as most of Indonesian people. All of the NPC group ate rice two or three times a day $(100 \%)$ and only one $(1.23 \%)$ in the non-NPC group ate sago as main food.

\section{Additional food}

Vegetables and fruits are eaten by $74.07 \%$ and $62.96 \%$ of the NPC group, and by $76.54 \%$ and $59.26 \%$ in the non NPC group respectively. However, only $27.16 \%$ drank milk every day in the non-NPC group compared with $42.21 \%$ in the NPC group and this difference was statistically not significant $(P=0.1098)$.

\section{Protein sources}

There are 4 kinds of protein sources taken by most Indonesian in their meals. Meat (beef, mutton, pork and fresh fish), taofu or soya bean curd, soya bean cake and salted fish. The last three were eaten in daily meal of most low income people in Indonesia.

In the NPC group meat, taofu, soya bean cake, and salted fish was taken by $45 \quad 05.06 \%, 82.72 \%$ and $33.33 \%$ of patients $r$ ective teast twice a week in their menu. In th ther gro , meat, taofu, soya bean cake was cen b, $7.90,24.07 \%$ and $71.60 \%$ of patien esp ively at salted fish was \begin{tabular}{llc} 
taken by only 13. & \\
\hline
\end{tabular}

Thu salted fish intake as a protein source was statistically significantly different between the two groups $(P<0.005)$.

\section{Smoking habit}

There were smokers in both groups; $49.38 \%$ in NPC group and only $32.10 \%$ in non-NPC group, but this difference was statistically not significant $\mathrm{O} O \mathrm{OR}=2.06$, $P=0.0251)$.

\section{Sources of energy}

Most of subjects used kerosene as the main source of energy for cooking (Table 5).

Table 5. Energy for cooking $(\mathrm{N}=81)$

\begin{tabular}{lcc}
\hline Source of energy & NPC \% (N) & Non-NPC \% (N) \\
\hline Wood & $18.52(15)$ & $7.41(6)$ \\
Kerosene & $65.43(53)$ & $59.26(48)$ \\
Gas (LPG) & $13.58(11)$ & $25.93(21)$ \\
Electricity & $2.47(2)$ & $7.41(6)$ \\
\hline
\end{tabular}

The difference in the usage of wood and kerosene between the NPC and non NPC group was statistically not significant; wood: $P=0.3075$, kerosene: $P=0.1098$. 


\section{Water sources}

Ground water was the main water source in most subjects; $70.10 \%$ of the NPC, and $62.90 \%$ of the non-NPC group used ground water. Clean water facilities was used by $28.40 \%$ of the NPC and $37.04 \%$ of the non-NPC group. Water deposit collected from rain fall was used by one patient of the NPC group $(1.24 \%)$.

The difference between ground water and clean water facilities used by the two groups was not statistically significant $(P=0,1501)$.

\section{Housing}

Most of the subjects lived with their family in a small house, usually out of the city (Table 6).

Table 6. Housing size of both group of patients

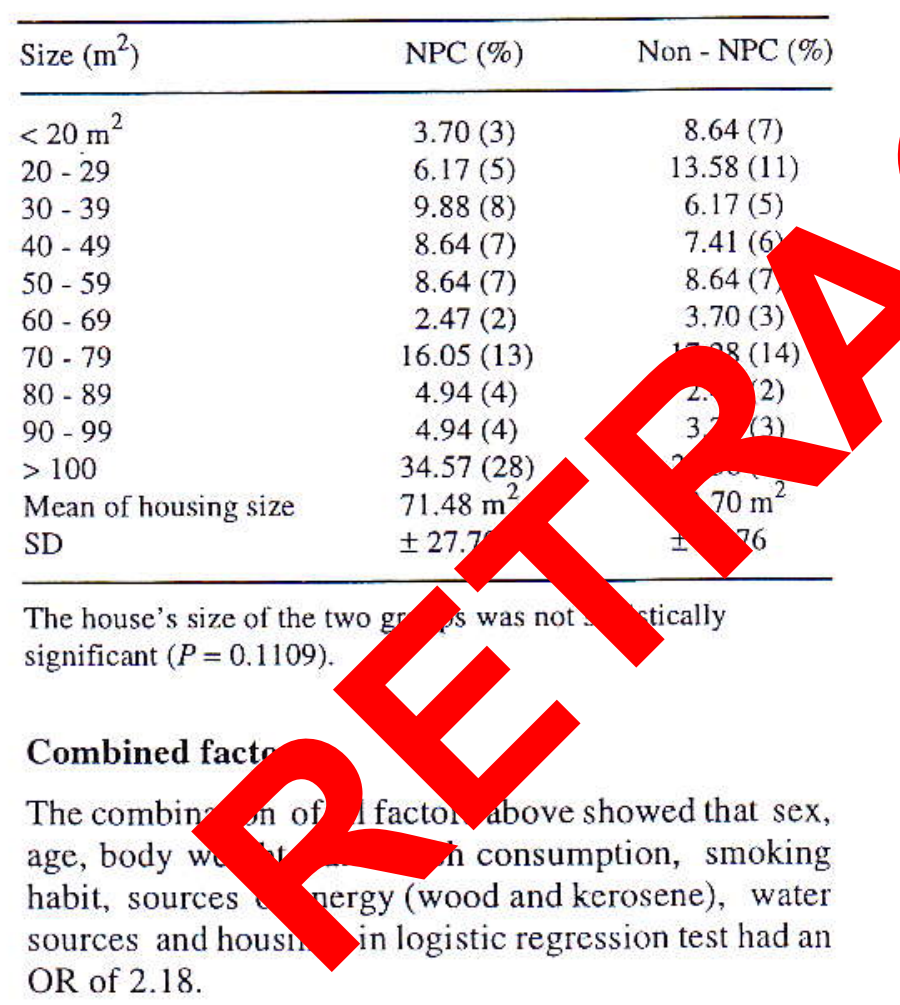

\section{DISCUSSION}

Sex ratio between male and female in this study was $1.8: 1$. It's a bit different with the figure mentioned by Shanmugaratnam who studied the epidemiology of $\operatorname{NPC}(2-3: 1)^{3}$

The highest incidence of NPC is in the $4^{\text {th }}$ decade of life. ${ }^{2,3}$ NPC occured most frequently around the fourth to fifth decade of life, and this is in agreement with this study. However, NPC patients. were also found at extremes of age such as 7 to 80 years old. ${ }^{4}$

Almost all of the NPC cases came on the late stage, 97.53\% came to the hospital in the stage III and IV. This is the typical figure of NPC patients in Jakarta, where we found the same figure in 1988-1992, i.e. stage I $0.90 \%$, stage II $2.94 \%$, stage III $18.78 \%$ and stage IV $77.38 \%$, or $96.16 \%$ were at stage III and IV from the 442 patients. ${ }^{5}$

Roezin $\mathrm{et} \mathrm{al}^{6}$ in 1989 also $\mathrm{b}$ same figure from 90 NPC patients, i.e. $3.7 \%$ stag $1.25 \%$ stage II, $13.33 \%$ stage III and $3 \%$ sta IV, or $95.56 \%$ were at stage III a $\mathrm{iV}$.

Most of the c. School gr dtes, t in non-NPC group most of them y High Sc graduates. There were more Unive, sty duates in the non-NPC than in the NPC gra As a le, the non-NPC group was more aucated than th NPC group. The monthly income evealed that the NPC patients came from the lower come ple compared to the non-NPC patients.

Normal and below normal body weight in the two aps showed nearly the same figure; 79.01 in the NPC and $83.95 \%$ in non-NPC group.

Almost all of the subjects in the two groups ate rice every day as well as most of Indonesian people, only one in the non-NPC group ate sago as the main carbohydrate source. In some people in east part of Indonesia sago is the main carbohydrate source and some other people in that region took corn as the main food.

In Jakarta, the meat price is much higher ( \pm 8 times) than taofu and soya bean cake, and the price of salted fish is about $80 \%$ of meat price. In this study the subjects comsumed salted fish only 50 to 75 grams in each meal because they ate much more rice than salted fish.

In the NPC group they ate meat less in frequency and quantity compared to the nen-NPC group $(45.68 \%$ and $67.90 \%$ ); in general, this showed that the NPC group came from lower economic class compared to the non NPC group. However, they ate more salted fish than the non-NPC group (33.33\% and $13.58 \%$ ), and this difference is statistically significant supposing the role of salted fish in predisposing NPC in this study.

The consumption of salted fish in Indonesian was very much different than people in China or Hong Kong. In 
China or Hongkong, they ate a lot of salted fish in each meal, every day for years since the weaning. A case control study in Hong Kong on cases under 35 years of age found a positive association of NPC with the consumption of salted fish at any time, but this association was particularly strong for the consumption during childhood. There was a relative increase in risk of nearly 40 fold for the consumption of salted fish once or more times a week at age of 10 , in comparison to rare consumption. ${ }^{7}$ Some experimental support for this association was provided by the study of $\mathrm{Yu}$ and Henderson in which rats fed salted fish developed tumors in the nasal cavity. ${ }^{8}$

Vegetables and fruits were consumed by both groups with about the same percentage. However, it was much different in drinking milk which percentage was higher in the NPC group because they believe that milk could increase their body resistance against cancer.

There was difference between smoking habit in the NPC group (49.38\%) compared to the non NPC group $(32.10 \%)$. Even it's not statistically significant, but the O.R. showed that the smokers have 2 times higher risk to have nasopharyngeal cancer than the nonsmokers.

Wood and kerosene were used more frequent amanergy source in the NPC compared with the non- $\rightarrow$ up, though those figures are statistically $\mathrm{n}$ ignif ant Both energy sources give more po usually used by lower income gro In the NPC group they used more gas an a icity as orgy sources compared to the NPS group. a whole the NPC group lived in mor oluted envir ment than non-NPC group.

Ground water ar by ndonesian people as water sour for rink a. other necessity. But some people in water from clean water facilities provide the goverment.

Ground water were more used by the NPC (70.10\%) compared to $62.90 \%$ in non-NPC group, but water supply by government were used more in non-NPC $(37.04 \%)$ than in NPC group $(28.40 \%)$. The clean water fascilities by goverment are not found in all parts of Jakarta, but the figures showed that the non NPC group was more wealthy than NPC group.

House size is one of the parameter of healthy life. The mean house size in NPC was $71.48 \mathrm{~m}^{2}$ compared to $63.70 \mathrm{~m}^{2}$ in non-NPC group. Eventhough it's not statistically significant, it showed that the NPC group had larger house than the non-NPC group.

The combined factors i.e. age, sex, body weight, smoking habit, salted fish consumption, souces of energy (wood and kerosene), water sources and housing showed that the NPC group had 2.18 times the risk to have nasopharyngeal carcinoma than non NPC group.

The other factor that was never proved before as an important risk factor of NPC in Indonesia was salted fish. However, this study revealed that salted fish played a role in increasing the of NPC.

CONCLUSION than female and ao verage of NPC patients was 45 years (be cen 50 ars). Most of the NPC patients from lo come status, live in more poluted an ment cursed by smoking habit and enerow source Gily used; as a whole the quality of l. mas less worthy compared to the non-NPC tients.

M. $4^{\text {th }}$ decade of life who ate salted fish more than twice a week, had a smoking habit and with a low economic condition had 2.18 times the possibility to have nasopharyngeal cancer than other people with better social economic and do not have salted fish in their meal.

\section{REFERENCES}

1. Weisburger JH, Horn CL. The Causes of Cancer. In : Holleb AI, Fink DB, Murahy GP, Editors. Clinical Oncology. American Cancer Society. Atlanta 1992: 80-106.

2. Ho JC. An Epidemiologic and Clinical Study of Nasopharyngeal Carcinoma. In: Van Hassett CA, Gibb AG, editors. Nasopharyngeal Carcinoma. Hong. Kong: The Chinese University Press, 1991:23-4.

3. Shannugaratnam K. Nasopharyngeal Carcinoma: Epidemiology and Aetiology. Proceedings of Nasopharyngeal Cancer Seminar; 1988, April 16; Semarang. Semarang: FK UNDIP, 1988:1-15.

4. Roezin A. Management of NPC in Indonesia. Asian J of Surgery. 1993; 16(4):274-9.

5. Soetjipto D, Roezin A, Rifki N. Nasopharyngeal carcinoma in Cipto Mangunkusumo General Hospital, Jakarta, Indonesia. Abstract of The XV World Congress of Otorhinolaryngology Head \& Neck Surgery; 1993, June 20-25; Istanbul, Ttrkiye. Istanbul: Organizing Committe of the Congress, 1993:296.

6. Roezin A. Prasojo D. Side effect of radiotherapy in NPC patients. Indonesia J Oncol 1993;4 (1):23-30. 
7. Yu MC, Ho JHC, Lai SH, Henderson BE. Cantonese style salted fish as a cause of NPC: Report of a case control study in Hong Kong. Cancer Res 1986; 46:956-61.

8. Yu MC, Henderson BE. Intake of Cantonese style salted fish as a cause of NPC. In : Tomatis L, Aitio A, Day NE, Heseltine
E, Kaldor J, Miller AB, et al, editors. Cancer: Causes, Occurrence and Control. IARC Scientific Publication No. 100. Lyon:IARC, 1990; 214.

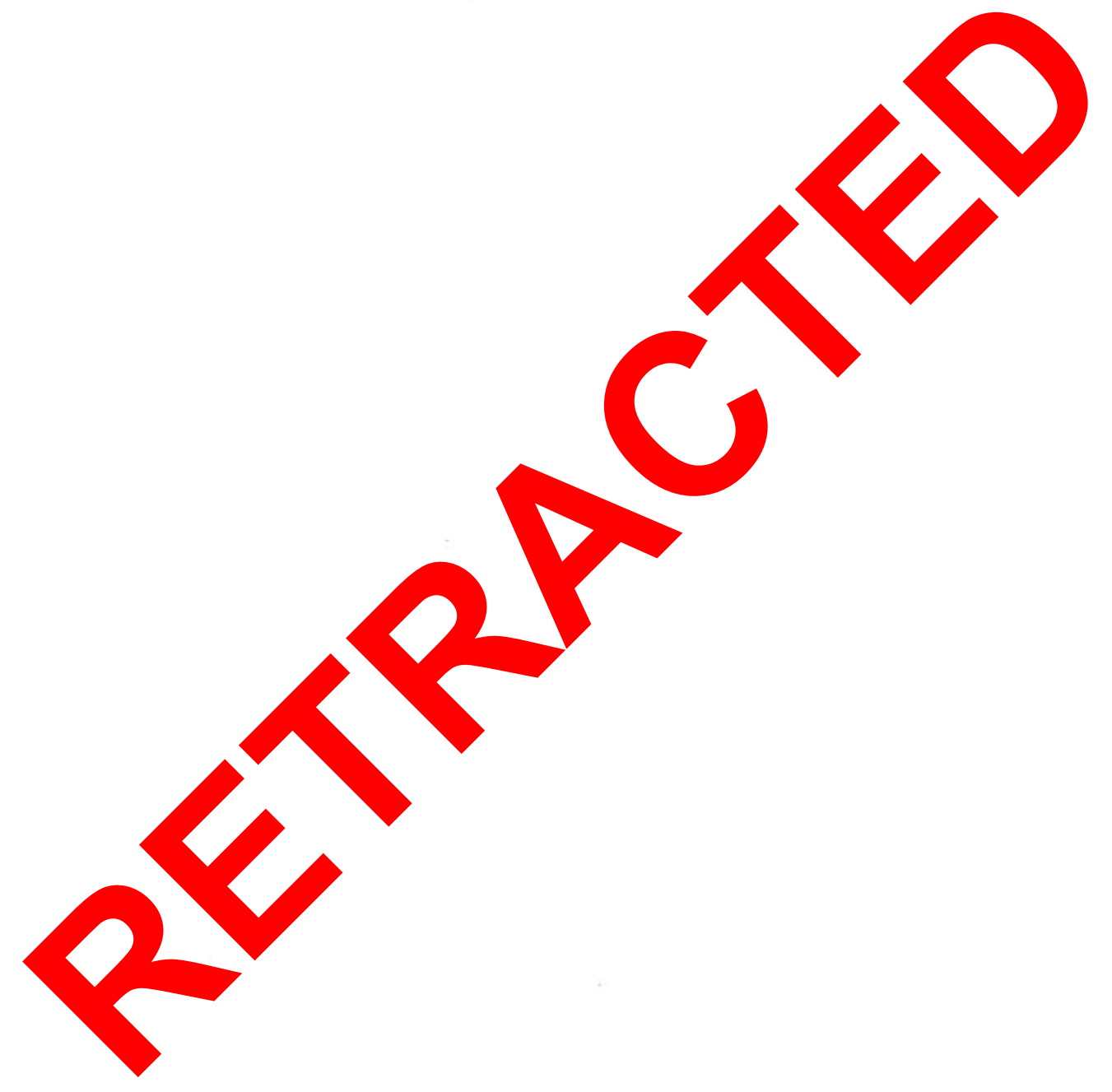

